\title{
PROSES PERSEPSI BAWAHAN PADA KEPEMIMPINAN ATASAN DIVISI HUMAS DPRD PROVINSI SULAWESI TENGAH
}

\author{
Dista Fatmalasari \\ Program Studi Ilmu Komunikasi FISIP Universitas Tadulako \\ Email:distafatmalasari@gmail.com
}

\begin{abstract}
ABSTRAK
Penelitian ini bertujuan untuk mengetahui persepsi bawahan pada kepemimpinan atasan divisi humas DPRD Provinsi Sulawesi Tengah. Tipe penelitian ini bersifat deskriptif kualitatif yaitu tipe ini digunakan untuk memberikan gambaran dan menguaraikan tentang keseluruhan objek yang diteliti sesuai dengan data yang diperoleh. Penelitian ini dilaksanakan di kantor DPRD Sulawesi Tengah pada bagian Divisi Humas dan Protokol. Penelitian ini melibatkan pimpinan dan staf divisi humas dan protokol Sulawesi Tengah. Konsep penelitian mengarah pada teori proses persepsi (Sobur 2003:446) yaitu seleksi, interpretasi dan reaksi. Teknik pengumpulan data dilakukan dengan cara observasi dan wawancara yang mendalam setelah itu hasil penelitian dipaparkan secara deskriptif. Hasil penelitian ini menunjukkan bahwa dengan adanya proses persepsi dapat dilakukan penilaian dengan cara menyeleksi karakteristik atasan yang menjabat memiliki sikap yang kurang baik dalam berbicara secara verbal yang ditunjukkan kepada staf humas dan protokol tersebut, setelah menyeleksi dapat dilakukan interpretasi pimpinan yang dinilai kurang profesional dalam memberikan tugas dan tanggung jawab kepada staf Humas DPRD Provinsi Sulawesi Tengah dengan SOP yang diberlaku, dan reaksi yang ditunjukkan staf Humas DPRD Provinsi Sulawesi Tengah melihat dan menilai tindakan yang dilakukan pimpinan terhadap staf kurang profesional dalam berkepemimpinan karena kurangnya kenyamanan dalam bekerja dan kurangnya menjalin komunikasi antara pimpinan dan bawahan.
\end{abstract}

\section{Kata Kunci: Humas; Persepsi; Proses}

\section{Submisission: 26 April 2021}

\section{Pendahuluan \\ Manusia sebagai makhluk sosial dan hidup berkelompok dalam kehidupan sehari-hari, tentu tidak luput dari interaksi atau komunikasi (Nur Inah, 2015). Komunikasi merupakan komponen yang paling penting dari kehidupan kita, karena kita dipaksa untuk berkomunikasi,}

terlepas dari sarana atau saluran yang digunakan(Dan, 2018). Komunikasi adalah suatu proses penyampaian berita dan ide dari suatu sumber berita ke suatu tempat tujuan(Zahara Abstrak, 2018). Komunikasi dapat terjadi dalam tataran komunikasi intrapribadi, antarpribadi, kelompok kecil, kelompok besar/public, 
organisasi dan komunikasi massa. Komunikasi intrapribadi adalah proses seseorang menerima informasi, mengolahnya, menyimpannya, dan menghasilkannya kembali (Yani, 2018). komunikasi antar pribadi didefinisikan sebagai komunikasi yang berlangsung antara dua orang yang mempunyai hubungan yang mantap dan jelas, seperti layaknya hubungan anak dan ayah (M. Handayani et al., 2017). Sekelompok orang yang jumlahnya lebih dari dua orang. Apabila jumlah orang dalam kelompok itu sedikit yang berarti kelompok itu kecil, komunikasi yang berlangsung disebut komunikasi kelompok kecil. Namun apabila jumlah orang dalam kelompoknya banyak berarti dinamakan komunikasi kelompok besar (Petra et al., 2017). organisai adalah unit sosial atau entitas sosial yang didirikan manusia untuk jangka waktu yang relatif lama,beranggotakan sekelompok manusia minimal dua orang, mempunyai kegiatan terkoordinir, teratur dan terstruktur, didirikan untuk mencapai tujuan terterntu dan mempunyai identitas diri yang membedakan satu entitas dengan entitas lainnya (Nudin, 2017). Komunikasi massa adalah komunikasi melalui media massa. Media massa dalam cakupan pengertian komunikasi massa itu adalah surat kabar, majalah, radio,televisi, atau film(Wilantari \& Memoriance, 2018).

Di dalam kelompok ataupun organisasi, selalu terdapat bentuk kepemimpinan yang merupakan masalah penting untuk kelangsungan hidup kelompok, yang terdiri dari atasan dan bawahannya (Baihaqi \& Martino, n.d.). Pencapaian kinerja pegawai yang efisien dipengaruhi oleh peran pimpinan dalam membangun dan mengarahkan bawahan karena pimpinan baik secara individu maupun sebagai anggota kelompok tidak dapat bekerja sendiri. Untuk itu, seorang pimpinan dituntut untuk dapat mengkomunikasikan hal-hal, baik yang berhubungan dengan pengarahan, tujuan, disiplin, perintah dan kebijaksanaan lainnya.

Humas dan Protokol adalah salah satu bagian Divisi di kantor DPRD Provinsi Sulawesi Tengah, Dewan Perwakilan Rakyat Daerah (DPRD) adalah lembaga perwakilan rakyat daerah yang berkedudukan sebagai unsur penyelenggara pemerintahan daerah di provinsi / kabupaten/kota) di Indonesia. Masalah yang terjadi di kantor DPRD Provinsi Sulawesi Tengah sebagai objek yaitu permasalahan internal antara atasan dan bawahan pada divisi Humas dan Protokol, permasalahan tersebut terjadi berawal dari pergantian Kasubag Humas dan Protokol lama ke Kabag Humas dan Protokol baru pada pertengahan bulan Agustus 2017. Dengan adanya Kabag baru tersebut, memungkinkan adanya kebijakankebijakan baru pula tentang programprogram kerja dan adanya perubahan cara pandang bawahan terhadap atasan. Dikarenakan adanya penilaian awal yang kurang baik seperti cara berkomunikasi yang kasar dan tidak menggunakan bahasa yang baik, serta berbicara dengan nada suara yang keras yang membuat bawahan langsung menilai buruk terhadap atasan tersebut, sehingga bawahan membandingkan atasan lama dan atasan baru. Atasan lama dikenal sebagai atasan yang berkomunikasi dengan bahasa yang halus dan lembut kepada setiap stafnya, dan setiap 
pekerjaan yang seharusnya dilakukan oleh bawahan dikerjakan oleh atasan, sehingga bawahan menjadi malas dan terbiasa dengan pekerjaan yang sedikit, namun atasan yang sedang menjabat saat ini berbeda dengan atasan sebelumnya yang melimpahkan pekerjaan kepada bawahan sesuai dengan SOP yang diberikan agar bawahan mengerti apa saja tugas dan fungsi humas. Atasan humas dan protokol DPRD Provinsi Sulawesi Tengah tidak ingin memanjakan bawahannya seperti yang dilakukan oleh atasan sebelumnya maka dari itu atasan yang sekarang menjabat sebagai kasubag humas dan protokol dinilai oleh bawahannya kurang memuaskan karena komitmen dan aturan yang dikeluarkan tidak sesuai dengan fakta yang ada.

\section{Tinjauan Pustaka}

\section{Definisi Komunikasi}

Sejalan dengan perkembangan ilmu komunikasi sebagai ilmu pengetahuan yang bersifat multidisipliner. Ilmu multidisipliner adalah ilmu yang pendekatannya dalam pemecahan suatu masalah dengan menggunakan tinjauan berbagai sudut pandang banyak ilmu yang relevan. definisi yang diberikan oleh para pakarpun semakin banyak dan beragam(Yuliaty et al., 2017). Menurut Carl I. Hovland mendefinisikan komunikasi sebagai: upaya yang sistematis untuk merumuskan secara tegas asas-asas penyampaian informasi serta pembentukan pendapat dan sikap(Nurmala, 2019).

$\begin{array}{crr}\text { Komunikasi Organisasi } & \\ \text { Menurut } & \text { Wiryanto } & \text { bahwa } \\ \text { komunikasi } & \text { organisasi } & \text { ialah }\end{array}$

pengiriman serta penerimaan beragam pesan organisasi di dalam kelompok formal atau informal dari suatu organisasi (Slamet Bambang Riono, 2020). Komunikasi formal adalah komunikasi yang disetujui dan berlaku dalam organisasi itu sendiri yang sifatnya berorientasi kepentingan organiasasi(Ahmad, 2016). komunikasi informal/ non formal,yaitu komunikasi yang tidak direncanakan dan tidak ditentukan dalam struktur organisasi (S. Handayani, 2017)

\section{Persepsi}

Secara etimologis, persepsi berasal berasal dari kata perception (Inggris) berasal dari bahasa latin perception; dari percipare yang artinya menerima atau mengambil (Hidayat, 2016). Sondang P. Siagian berpendapat bahwa persepsi merupakan suatu proses dimana seseorang mengorganisasikan dan menginterperstasikan kesan-kesan sensorisnya dalam usahanya memberikan suatu makna tertentu dalam lingkunganya (Effendy \& Sunarsi, 2020). Persepsi pada hakikatnya adalah proses kognitif yang dialami oleh setiap orang didalam memehami informasi tentang lingkungannya, baik lewat pengelihatan,pendengaran, penghayatan,perasaan, dan penciuman (Effendy \& Sunarsi, 2020).

\section{Proses Persepsi}

Bimo Walgito menyatakan bahwa terjadinya persepsi melalui beberapa tahapan proses sebagai berikut: (a) Proses fisik, merupakan proses ditangkapnya suatu stimulus oleh alat indera manusia; (b) Proses fisiologis, merupakan proses diteruskannya 
stimulus yang diterima oleh alat indra melalui saraf sensoris ke dalam otak; (c) Proses psikologis, merupakan proses timbulnya kesadaran individu tentang stimulus yang diterima oleh alat indra. Proses ini merupakan proses terakhir dan merupakan persepsi sebenarnya. Selanjutnya,respon sebagai akibat dari persepsi dapatdiambil oleh individu dalam berbagai macambentuk (Thomas, 2016).

\section{Metode Penelitian}

Tipe penelitian yang digunakan dalam penelitian ini adalah penelitian deskriptif kualitatif, karena di tinjau dari pembahasan masalahnya serta hasil yang akan di capai penelitian ini yaitu proses persepsi bawahan pada kepemimpinan atasan divisi Humas dan Protokol DPRD Provinsi Sulawesi Tengah. Penelitian deskriptif menurut Whitney yaitu penelitian untuk mencari fakta dengan interpretasi yang tepat (Anton et al., 2016). Moleong menyatakan bahwa penelitian kualitatif bermaksud untuk memahami fenomena tentang apa yang dialami oleh subjek penelitian, misalnya perilaku, persepsi, motivasi, tindakan, dan lain-lain secara holistik dan dengan cara deskripsi dalam bentuk kata-kata dan bahasa, pada suatu konteks khusus yang alamiah dan dengan memanfaatkan berbagai metode alamiah (Pradana, 2016).

Lokasi penelitian ini dilakukan di kantor DPRD Provinsi Sulawesi Tengah. Pemilihan kantor DPRD sebagai lokasi penelitian ini, karena melihat adanya masalah yang terjadi pada atasan dan bawahan di divisi Humas dan Protokol DPRD Sulawesi Tengah. Dalam hal ini, bagaimana proses persepsi bawahan terhadap kepemimpinan atasan divisi Humas dan Protokol DPRD Provinsi Sulawesi
Tengah. Subjek penelitian yaitu orangorang yang dipilih diwawancarai atau diobservasi sesuai tujuan riset atau yang dapat disebut dengan informan. Subjek penelitian yaitu orang-orang yang dipilih diwawancarai atau diobservasi sesuai tujuan riset atau yang dapat disebut dengan informan. Kemudian tehnik sampling yang diambil adalah purposive sampling yaitu teknik pengambilan sampel sumber data dengan pertimbangan tertentu. Pertimbangan tertentu ini, misalnya orang tersebut yang dianggap paling tahu tentang apa yang kita harapkan, atau mungkin dia sebagai penguasa sehingga akan memudahkan peneliti menjelajahi obyek atau situasi sosial yang diteliti (Ayu \& Purba, 2017)

Teknik ini mencakup kriteria tertentu yang dibuat peneliti berdasarkan tujuan penelitian. Adapun kriteria yaitu orang-orang yang bekerja pada bidang kehumasan DPRD Provinsi Sulawesi Tengah, dan mengetahui kinerja atasan lama dan atasan baru sehingga mereka membandingkan kinerja atasan baru selama menjabat sebagai kasubag Humas dan Protokol DPRD Provinsi Sulawesi Tengah.

\section{Hasil Penelitian}

Dari hasil penelitian penulis mengunakan proses persepsi bawahan untuk mengetahui kinerja atasan pada divisi humas dan protokol DPRD Provinsi Sulawesi Tengah yang dianggap masih sangat kurang dalam melakukan tugas dan tanggung jawab sebagai atasan. Dengan adanya metode persepsi komunikasi terhadap atasan sehingga bawahan humas dan protokol DPRD Provinsi Sulawesi Tengah bisa mempresepsikan proses 
kerja dan tingkah laku atasan selama menjabat sebagai kasubag humas \& protokol, karena selama ini bawahan menilai kurang baik terhadap atasan yang sekarang disebabkan atasan yang kurang profesional dalam bekerja, sikap yang ditunjukan selama ini kurang baik dimata bawahan dan cara berkomunikasi yang digunakan secara verbal selama ini tidak menunjukkan selayaknya seorang atasan ketika sedang adanya rapat maupun berbicara secara langsung dengan menggunakan bahasa yang tidak semestinya pimpinan ucapkan kepada bawahan maka dari itu staff humas kurang respect. Keberadaan seorang atasan humas yang tidak hanya ahli dan berpengalaman, tetapi juga didukung oleh sumber-sumber daya yang modern.

Adanya hubungan komunikasi yang terus menerus dilakukan atasan terhadap bawahan dalam rangka menyampaikan informasi/pesan mengenai kebijakan tugas dan fungsi humas terhadap bawahan. Maka hal itu menimbulkan kesan/persepsi dari bawahan terhadap tugas dan tanggung jawab sebagai seorang humas tersebut. Persepsi bawahan merupakan kesan yang muncul sebagai akibat dari pengalaman yang diterima dari atasan atau dari lingkungan kerja atau bisa dikatakan persepsi yang dirasakan oleh bawahan merupakan persepsi emosional seorang manusia yang didapat ketika mendapatkan rangsangan dari seorang atasana dilingkungan humas dan protokol sehingga memunculkan penilaian terhadap kinerja atasan tersebut yang mengandung resiko. Persepsi yang diberikan bawahan terhadap atasan humas akan positif apabila dalam melakukan kegiatannya atasan humas selalu memberikan yang terbaik untuk setiap bawahan di divisi humas dan protokol atau sebaliknya. Untuk itu, agar persepsi yang di munculkan positif, maka atasan humas harus memaksimalkan kinerjanya dalam membantu setiap tugas dan fungsi untuk mewujudkan tujuan sesuai dengan visi misi yang ada.

Atasan humas dan protokol DPRD Provinsi Sulawesi Tengah sudah memberikan yang terbaik kepada bawahan, dan memberikan tugas dan tanggung jawab yang ada agar bawahan mengetahui tugas dan tanggung jawabnya sebagai staff divisi humas dan protokol. Atasan humas dan protokol bersikap tegas kepada bawahan yang tidak mengikuti aturan yang ada di humas. Semua pekerjaan dilimpahkan kepada setiap bawahan sesuai tugas - tugas mereka agar staff humas mendapatkan tanggung jawab masing - masing. Akan tetapi bawahan masih menilai negatif atasan divisi humas dan protokol karena tugas dan fungsi humas yang diberikan tidak sesuai aturan yang ada sehingga sebagian staff humas tidak mengetahui tugas dan tanggung jawab mereka sebagai staff humas, dan cara komunikasi yang digunakan oleh atasan masih kurang sopan dan bawahan menilai atasan masih kurang profesional dalam bekerja, atasan juga dinilai masih kurang dalam menangani setiap permasalahan yang ada di divisi humas dan protokol baik secara eksternal maupun internal.

Bawahan humas dan protokol DPRD Provinsi Sulawesi Tengah terbiasa dengan proses kerja yang diterapkan oleh atasan sebelumnya yang selalu memanjakan bawahannya, setiap tugas dan fungsi yang semestinya menjadi tanggung jawab 
bawahan malahan dilimpahkan kepada atasan. Namun atasan yang sedang menjabat saat ini berbeda dengan atasan sebelumnya yang melimpahkan pekerjaan kepada bawahan sesuai dengan SOP yang diberikan agar bawahan mengerti apa saja tugas dan fungsi humas. Atasan humas dan protokol DPRD Provinsi Sulawesi Tengah tidak ingin memanjakan bawahannya seperti yang dilakukan oleh atasan sebelumnya maka dari itu atasan yang sekarang menjabat sebagai kasubag humas dan protokol dinilai oleh bawahannya kurang memuaskan karena komitmen dan aturan yang dikeluarkan tidak sesuai dengan fakta yang ada.

\section{Seleksi}

Bawahan menilai atasan yang sekarang menjabat memiliki karakteristik yang kurang baik dan memiliki sifat yang angkuh yang tidak semestinya ditunjukkan oleh seorang atasan. Akan tetapi ada sebagian bawahan yang melihat kinerja dan karakteristik atasan humas sangat baik. Penilaian seorang bawahan sangat berbeda beda karena beberapa bawahan lebih dulu mengenal atasan yang sekarang menjabat sehinga paham mengenai sikap dan sifat atasan yang memang tegas dan professional, namun sebagian bawahan malah menilai sikap dan sifat atasan terlalu menjaga jarak kepada bawahan yang baru mengenalnya.

Bawahan humas dan protokol DPRD Provinsi Sulawesi Tengah belum mengetahui tugas dan fungsi humas yang sesungguhnya karena mereka terbiasa dengan pekerjaan yang diatasi sendiri oleh atasan yang sebelumnya menjabat sedangkan atasan humas dan protokol yang sekarang menjabat memberikan tugas dan tanggung jawab kepada bawahan sesuai dengan SOP yang berlaku sehingga mereka mengerjakan segala tugas - tugas sesuai dengan fungsi humas yang sesungguhnya. Informasi yang diberikan oleh atasan humas dan protokol DPRD Provinsi Sulawesi Tengah dinilai kurang dipahami oleh setiap bawahan divisi humas, seringkali bawahan bingung mengerjakan pekerjaan yang tidak sesuai dengan tugas fungsi mereka di divisi humas karena kurangnya informasi yang diberikan oleh atasan kepada bawahan pada saat rapat.

Pimpinan seharusnya dapat menyadari juga bahwa seorang pemimpin tidak dapat menentukan strategi yang tepat bilamana tidak mendalami fungsi humas dan peraturannya, maka dapat dikatakan bahwa humas dan peraturannya terlibat dan bersifat integratif dalam manajemen kantor tempatnya bekerja, namun kenyataannya tidak semua pemegang kekuasaan di sebuah kantor memerlukan "tangan terampil" dari seorang humas. Perbedaan pandangan para pemimpin mengenai penting tidaknya humas ataupun tentang kemampuan yang dimiliki oleh humas akan berdampak pada posisi humas di dalam kantor sehingga mengakibatkan kedudukan humas pada lembagalembaga tersebut tidak sebagaimana mestinya.

\section{Interpretasi}

Selama ini bawahan dan protokol DPRD Provinsi Sulawesi Tengah menilai cara berkomunikasi yang dilakukan seorang atasan baik secara lisan maupun melalui gerakan masih sangat kurang berkompoten. Cara berkomunikasi yang digunakan 
atasan pada saat berinteraksi masih kurang sopan dan masih menggunakan bahasa yang kurang baik dan selalu bernada tinggi, proses penyampaian pesan yang dilakukan atasan kepada bawahan belum tersampaikan dengan baik sebagian staff humas masih kurang paham dengan bahasa pada saat atasan memberikan arahan kepada bawahan karena terlalu menggunakan bahasa yang kurang dimengerti sehingga terjadinya keterhambatan dalam proses penyampaian pesan antara atasan dan bawahan, sehingga bawahan menyalah artikan penyampaian yang diberikan atasan.

Komunikasi atasan dan bawahan ini sangat penting dalam divisi humas dan protokol karena dapat membawa pengaruh besar dalam kinerja terhadap seluruh staff divisi humas. Adanya hubungan komunikasi atasan dengan bawahan yang efektif dapat menciptakan suatu kondisi yang menyenangkan dalam divisi humas dan protokol, yang kemudian berpengaruh terhadap kepercayaan dan kepuasan bawahan yang pada akhirnya ikut menentukan kinerja bawahan. Komunikasi menumbuhkan motivasi dengan cara menjelaskan kepadda karyawan apa yang harus dilakukan, bagaimana prestasi mereka, dan apa yang bisa dilakukan untuk meningkatkna kinerja. Selain itu, melalui komunikasi perilaku karyawan bisa dipengaruhi oleh komunikasi, komunikasi memungkinkan terjadinya kerja sama yang harmonis antara atasan kepada bawahan dan antar bawahan dengan bawahan. Bila hubungan atasan dengan bawahan dapat diperkokoh maka sumber daya manusia diseluruh divisi dapat di tingkatkan. Namun bawahan merasa atasan humas dan protokol DPRD Provinsi Sulawesi Tengah setiap memberikan tugas kepada bawahan tidak sesuai dengan fungsi dan tanggung jawabnya masing - masing, bawahan juga menilai atasan tidak professional dalam melakukan pekerjaan dan tindakan yang dilakukan belum sesuai dengan apa yang direncanakan.

\section{Reaksi}

Seperti bawahan di divisi humas dan protokol yang menilai kinerja atasan secara negatif karena proses kerja yang dilakukan kurang maksimal dengan apa yang diharapkan oleh bawahan. Bawahan humas dan protokol DPRD Provinsi Sulawesi Tengah menilai proses komunikasi yang dilakukan atasan masih sangat kurang baik dalam menyampaikan pesan dan seringkali mengalami hambatan dalam berkomunikasi, karena bahasa yang digunakan tidak menggambarkan bahwa dia seorang atasan.

Aliran komunikasi ditentukan oleh sikap atasan divisi humas dan protokol DPRD Provinsi Sulawesi Tengah, hal ini akan berdampak pada peningkatan kinerja bawahan dimana adanya komunikasi yang efektif pada divisi humas dan protokol yang akan membuat atasan menentukan sikap kepemimpnannya yang sesuai dengan komunikasi yang ada pada divisi humas dan protokol tersebut, sehingga bawahan menjadi nyaman dan paham akan tugas-tugas yang harus diselesaikan dan meningkatkan kinerjanya dalam bekerja. Oleh karena itu, sikap atasan harus tegas untuk pengaruh positif antara komunikasi atasan dan kinerja bawahan agar tidak menimbulkan permasalahan yang 
mengakibatkan hubungan atasan dan bawahan menjadi tidak harmonis.

Kinerja pimpinan sebagai pemimpin masih kurang mampu untuk memakai kekuasaan dengan efektif, sehingga aktifitas untuk melaksanakan pekerjaan dan tugas tidak dapat dilakukan dengan baik.

Bawahan divisi humas mengharapkan atasan yang bersikap professional dan adil dalam bekerja sehingga staff merasa nyaman dibawa arahan kasubag baru sehingga tidak merasa tertekan saat melakukan pekerjaan yang diberikan. Kurang tegasnya atasan dalam memberikan sanksi kepada bawahan yang tidak disiplin menyebabkan tingginya angka absensi bawahan yang berpengaruh terhadap menurunnya kualitas dan kuantitas pekerjaan. Tidak tegasnya atasan dalam memberi sanksi kepada bawahan yang tidak disiplin juga membuat beberapa dari bawahan merasa iri terhadap temannya yang tidak disiplin namun tidak diberi sanksi yang tegas oleh atasan sehingga menyebabkan bawahan lain juga ikutikutan untuk tidak disiplin dalam hal ini adalah tidak disiplinnya waktu dalam bekerja seperti pada saat jam bekerja bawahan datang hanya untuk mengisi absensi kehadiran dan tidak berada di dalam ruangan, beberapa dari mereka kembali ke kantor pada saat jam pulang kerja hanya untuk mengisi absen pulang.

Kebijakan sangat dibutuhkan dan harus dilakukan oleh seorang pemimpin, karena bagi staf memiliki pemimpin yang bijaksana merupakan kenyamanan dalam lingkungan pekerjaan yang juga dapat membuat staf merasa nyaman dan tentram dalam proses bekerja yang mereka lakukan, namun untuk menjadi pemimpin yang berlaku bijaksanan bukanlah hal yang mudah untuk dilakukakan, karena terkadang keegoisan yang selalu merajai diri pribadi manusia untuk berlaku bijak.

\section{Kesimpulan}

Berdasarkan hasil penilitian dan pembahasan tentang " Proses persepsi bawahan pada kepemimpinan atasan divisi humas DPRD Provinsi Sulawesi Tengah" maka dapat ditarik kesimpulan bahwa dari awal menjabat kasubag baru sudah memiliki penilaian negatif dari bawahan karena sikap yang ditunjukan sangat angkuh sehingga bawahan mempresepsikan atasan kasubag memiliki sifat yang tidak bertanggung jawab terhadap bawahannya. Bawahan divisi humas DPRD Provinsi Sulawesi tengah melihat kinerja atasan sangat buruk karena tidak adanya pembagian tugas dan fungsi yang diberikan oleh atasan kepada bawahan sehingga pekerjaan yang mereka lakukan tidak sesuai SOP yang ada.

Atasan Humas DPRD Provinsi Sulawesi Tengah memiliki cara berkomunikasi yang kurang baik kepada bawahan dan tidak tegas kepada bawahan yang melakukan pelanggaran. Bawahan menilai atasan humas hanya melakukan komunikasi secara baik hanya kepada staff yang dekat kepadanya, dan kurang tegasnya dalam memimpin sehingga bawahan mempresepsikan kinerja selama ini kurang baik dan tidak seharusnya dilakukan seorang pemimipin, karena atasan yang bijaksana itu harus menunjukkan sikap yang tegas dan tanggung jawab kepada setiap bawahan didivisi humas. Cara berkomunikasi yang kasar dan tidak menggunakan bahasa yang baik pada saat melakukan interaksi kepada bawahan sehingga atasan dinilai sangat buruk, dan kurangnya sikap yang tegas pada saat pengambilan keputusan 
membuat bahawan berfikir bahwa atasan seharusnya memberikan solusi dan masukan pada saat terjadinya masalah namun yang dilakukan atasan humas hanya meminta masukan kebawahan dan bukan sikap yang semestinya ditujukan seorang atasan.

\section{Referensi}

Ahmad, A. (2016). Dinamika Komunikasi Dalam Pembangunan Desa Wisata Brayut Kabupaten Sleman Dinamika Komunikasi Dalam Pembangunan Desa Wisata Brayut Dynamics of Communication in The Development on Tourist Village.

Anton, O., Prihartono, W., \& Sos, S. (2016). Surat Kabar \& Konvergensi Media (Studi Deskriptif Kualitatif Model Konvergensi Media Pada Solopos). CHANNEL: Jurnal Komunikasi, 4(1), 105-116. https://doi.org/10.12928/channel. v4i1.4210

Ayu, I., \& Purba, G. (2017). Pengaruh Partisipasi Penganggaran, Asimetri Informasi, Dan Budaya Organisasi Pada Senjangan Anggaran. E-Jurnal Akuntansi, 12(3), 770-785.

Baihaqi, A., \& Martino, R. (n.d.). Efek Komunikasi dalam Organisasi Karang Taruna Abstrak. 54-78.

Dan, E. (2018). Komunikasi Organisasi (Suatu Tinjauan Teoritis Dan Praktis).

Effendy, A. A., \& Sunarsi, D. (2020). Persepsi Mahasiswa Terhadap Kemampuan Dalam Mendirikan UMKM Dan Efektivitas Promosi Melalui Online Di Kota
Tangerang Selatan. JURNAL ILMIAH MEA (Manajemen, Ekonomi, Dan Akuntansi), 4(3), 702-714. https://journal.stiemb.ac.id/index .php/mea/article/download/571/2 48

Handayani, M., Penelitian, P., Pendidikan, K., \& Kemdikbud, B. (2017). Pencegahan Kasus Kekerasan Seksual Pada Anak Melalui Prevention of Sexual Violence Cases in Children Through Interpersonal Communication. Jurnal Ilmiah VISI PGTK PAUD Dan DIKMAS, 12(1), 67-80. journal.unj.ac.id/unj/index.php/ji v/article/download/2805/2091

Handayani, S. (2017). Peningkatan Profesional Guru.

Hidayat, W. (2016). Persepsi Siswa Sma Kota Parepare Tentang Stain Parepare.

Nudin, B. (2017). Peran Budaya Organisasi IPNU-IPPNU. EL TARBAWI, 10(1). https://doi.org/10.20885/tarbawi. vol9.iss 1.art5

Nur Inah, E. (2015). Peran Komunikasi Dalam Interaksi Guru Dan Siswa. Al-Ta'dib, 8(2), 150-167.

Nurmala. (2019). Model Komunikasi Persuasif Dalam Perspektif Islam. IX(2), 115-130.

Petra, U. K., Lukman, O. P., Tjahjo, J. D. W., Aritonang, A. I., Komunikasi, I., Kristen, U., \& Surabaya, P. (2017). Komunikasi Kelompok Antara Koordinator dan Anggota Kelompok Suporter Persebaya Surabaya ( Bonekmania ) Dalam Memperbaiki Citra. 6(2), 1-10. Pradana, Y. (2016). Pengembangan 
Karakter Siswa Melalui Budaya Sekolah (Studi Deskriptif Di Sd Amaliah Ciawi Bogor). Untirta Civic Education Journal, 1(1), 55-67.

https://jurnal.untirta.ac.id/index. $\mathrm{php} / \mathrm{UCEJ} /$ article/view/1330

Slamet Bambang Riono, M. S. dan S.

N. U. (2020). Pengaruh

Komunikasi Organisasi, Budaya Organisasi, dan Komitmen Organisasi terhadap Kinerja Pegawai di Rumah Sakit dr. Soeselo Kabupaten Tegal. Syntax Idea, 2(4), 138-147. https://doi.org/https://doi.org/10. 36418/syntax-idea.v2i4.190

Thomas, R. (2016). Persepsi

Masyarakat Terhadap Kualitas

Pelayanan Dalam Pembuatan EKTP Di Kecamatan Tulung Selapan Kabupaten Ogan Komering Ilir ( OKI ). Jurnal Ilmu Administrasi Publik, 4(2), 189-201.

Wilantari, N. N. A., \& Memoriance, -. (2018). Komunikasi Massa dalam Manajemen Pariwisata. Dharma Duta, 16(1). https://doi.org/10.33363/dd.v16i 1.139

Yani, W. O. N. (2018). Komunikasi Intrapribadi Dalam Membentuk Sikap Percaya Diri Melalui Neuro Linguistic Programming Intrapersonal Communication In Forming The Attitude Of Confidence Through Neuro Linguistic Programming. 124135.

Yuliaty, K., Putri, S., Larasati, M., Tuti, P., Bekti, W. S., Salsabila, I., \& Pendahuluan, A. (2017). Tantangan Ilmu Komunikasi dari Aspek Komunikasi Bisnis dalam Ilmu Multidisipliner.
Zahara Abstrak, E. (2018). Peranan Komunikasi Organisasi Bagi Pimpinan Organisasi. In Warta Dharmawangsa (Vol. 0, Issue 56). http://jurnal.dharmawangsa.ac.id /index.php/juwarta/article/view/8 